\title{
Public Perceptions of Grab Online Taxi Activity in Sub-District of Tataaran 1 South Tondano District Minahasa Regency
}

\author{
Abd. Rasyid Umaternate* \\ Sociology Education Department \\ Faculty of Social Science \\ Universitas Negeri Manado \\ Tondano, Indonesia \\ rasyidumaternate@unima.ac.id \\ Alan Samau \\ Sociology Study Program \\ Faculty of Social Sciences, Manado \\ State University \\ Manado, North Sulawesi \\ alansamau@unima.ac.id
}

\author{
Ferdinand Kerebungu \\ Sosiology Education Department \\ Fakulty of Social Science, Manado \\ State University \\ Manado, North Sulawesi \\ ferdinankerebungu@unima.ac.id
}

\author{
Awaluddin Hasrin \\ Sosiology Education Department \\ Faculty of Social Science \\ Universitas Negeri Manado \\ Tondano, Indonesia \\ awaluddinhasrin@unima.ac.id
}

\begin{abstract}
Sub-district Tataaran I, South Tondano District, Minahasa Regency is a village located close to Universitas Negeri Manado (UNIMA). The community is not only a native of the sub-district but has also been mixed with many students who live in Tataaran. They need transportation in their activities. But now it is starting to clash between public transportation drivers and Grap line taxi facilities that operate around the Tataaran sub-district I. Often Grab taxi passengers feel uncomfortable due to public transportation drivers (angkot) do not hesitate to commit acts of violence for taxi passengers online Grap and forced to get off to take public transportation, but residents still use taxis on the Grap line. What is the perception of the community of Tataaran I sub-district on the Grap line taxi activity that is the problem of this research? This study aims to explain the public perception of Online Taxi Grab Activity in sub-district of Tataaran I, South Tondano District. For the literature review on the problem of this research, sociologically it is placed as a phenomenon of social interaction and community perception. The method used is a qualitative research method using data collection techniques through interviews and observations. Data Analysis Techniques use the Interactive Model. The results showed the public perception of the Tataaran 1 sub-district on Grap Activities can be seen from three important aspects, namely from the aspects of the benefits, time and cost of online taxis. From the aspect of the benefits that using Grab makes it easier to do activities even more on pick up according to the point or (location) even though the house is far from the highway and delivered to the destination. In terms of time, using grab speeds up to different destinations than public transportation which are circling, taking other passengers. In terms of cost, they are very happy due to they can be reached, especially also the offer of bonuses, making it easier for users to get a bonus when using a taxi on the Grab line.
\end{abstract}

Keywords: Online Grab, Community Perception

\section{INTRODUCTION}

Transportation or public transportation is a very important field of activity in the life of the Indonesian people. Recognizing the important role of transportation, the traffic and road transportation should be arranged in an integrated national transportation system and be able to realize the availability of transportation services according to the level of traffic needs and orderly, convenient, fast, smooth and low-cost transportation services.

Humans as social beings have many needs should be fulfilled for their welfare. These needs may not be fulfilled in one location. Therefore, humans need transportation to move people and / or goods from one place to another by using a vehicle. Judging from the characteristics of the types of use, modes of transportation of people can be divided into private vehicles and public vehicles. Private vehicles are operated only for people who own these vehicles. Public vehicles are provided for use by the public at a fee. Public vehicles can be categorized into vehicles that are rented (paratransit) and ordinary public vehicles (transit).

Public transportation has an important role in economic development, to get the sustainability of public transportation, serious handling is needed. Transport is an important element in the economy due to it is related to the distribution of goods, services, and labor, and is the core of the economic movement in cities, various forms of public transportation modes with the characteristics and level of service provided coloring the development of the city's public transportation system which should be oriented towards security and convenience for they can compete with private transportation. Economic development requires adequate and adequate transportation services. Without the presence of public transportation as a means of support, it is not expected that satisfying results will be achieved in the economic development of a country.

Land transportation in urban areas requires an effective and efficient transportation system to serve the 
transfer of goods and people within the boundaries between regions, for the various available resources can be obtained and utilized for the benefit of all humans. Specifically, regarding the transfer of goods, the quality of goods transportation services should be conducted effectively and efficiently in a smooth, safe, orderly, responsible and inexpensive manner. Along with these developments, information and communication technology has a great influence on the global community as its users. These developments encourage the change of conventional communication into modern communication with a digital lifestyle. And this also affects the behavior of the community itself in interacting and communicating.

The presence of increasingly sophisticated technology is inevitable by the community. Technology gave birth to a variety of business models including business which is currently a phenomenon in the community, namely online transportation services such as Go-Jek, Grab, Uber and other transportation services. People can use this online transportation service by using their smartphone after downloading the service application.

Indeed, the presence of online transportation services provides satisfaction to the needs of the public in transportation. The public can use this service easily, cheaply, safely and comfortably. The presence of online transportation answers the needs of the community for everything can be done practically. Prospective passengers no longer need to approach the motorcycle taxi station or stand on the edge of the road to stop a taxi or even be involved in the process of bargaining for a price to take a journey to be addressed.

The jealousy of the micro drivers keeps getting in contact with each other when they see a car carrying passengers and according to them it is an Online Taxi or Grab, they will tell their friends to trip the taxi, for many passengers from this Grab feel uncomfortable other than due to their actions are not reluctant to commit violence the passengers are forced to get off and ride the micro. According to one of the people who have experienced this they are not happy about this they say that this is a very bad deed they order an online taxi due to the circumstances force them to rush to work if they take a micro ride they sometimes slow and will become they will be late to their place of work, this is also the same said by students who have been trip by micro drivers because they take an online Grab taxi.

The focus of the problem in this study is: About Community Perception of Online Taxi Activities in Subdistrict of Tataaran I, South Tondano District. Based on the background, the formulation of the problem in this study was formulated as follows: What is the Community's Perception of Online Taxi Grab Activities in Sub-district of Tataaran I, South Tondano District?

\section{RESEARCH METHODS}

In this study the method used is qualitative. This study uses techniques, interviews and participatory observation. According to reference [1] unstructured interviews, interviews are free where researchers do not use interview guidelines that have been arranged systematically and completely for the collection of data. The interview guidelines used only outline the issues to be raised. According to reference [2] in this observation, researchers are involved with the daily activities of people who are being observed or used as sources of research data. Based on the formulation of the problem, the focus of this research is: Public perception of the existence of an online taxi in Tataran Sub-district. The informants of this research are determined based on the research objectives and certain considerations, from government agencies/institutions and local communities who are domiciled in Sub-district of Tataran 1. With these goals and considerations, the informants for the community and family in Tataaran 2, employees, students and the local community.

Data collection is conducted as follows, (1) determining the scope of the study, (2) collecting data or information through observation and interviews. The descriptions below are some of the data collection techniques used by researchers to capture data from informants.

The data analysis technique is the process of systematically searching and compiling data obtained from interviews, field notes and other materials, for they can be easily understood for all can be shared with others. Qualitative data analysis according to reference [3] includes three components of analysis, namely: Data reduction. Data reduction is defined as the selection, concentration, attention to simplification, abstracting and transformation of rough data arising from written records in the field. Data reduction is a form of analysis sharpens, directs, classifies, discards unnecessary, organizes data in such a way the conclusions can finally be drawn and verified, the method used in data reduction can be through a long selection, through a summary or a brief description classify them into a broader pattern.

Validation of data is done by following the instructions reference [1], which states the data validity test in qualitative research includes tests, credibility (internal validity), transferability (external validity), dependability (reliability), and confirmability, (objectivity)

1. The degree of trust (credibility), to determine the degree of trust in this study used triangulation. Triangulation in this credibility test is defined as checking data from various sources in various ways. There are several triangulation techniques, but for this study triangulation techniques are used to test the credibility of the data, which is done by checking the data to the same source with different techniques. Data obtained from respondents by interview checked again by observation or questionnaire. If the three data credibility testing techniques produce different data, discussions will be held again with the relevant data source or others, to ascertain which data is correct.

2. Transferability testing is external validity, which shows the degree of accuracy, or the applicability of the results of the study to the population where the research was conducted. This transfer value is pleased with the question 
to what extent the research results can be used in other situations.

\section{RESULTS AND DISCUSSION}

\section{Research sites}

In Sub-district of Tataaran I there are obsidian rocks with a potential of millions of cubic meters. These rocks are useful for building materials and processing of glass raw materials. This land is a community property that is managed by the community itself for local needs.

The boundaries Sub-district of Tataaran I are as follows:
North
: Tomohon City
East
Tondano
West
: Rurukan
South
: UNIMA Campus

Tataran I Village has a population of 1016 people consisting of 303 families.

Table 1 Tataran I Village has a population

Tabel 2 Inhabitant according to Gender and Age

\begin{tabular}{|c|c|c|c|}
\hline Age Group & Male & Female & Total \\
\hline $0-5$ & 45 & 40 & 85 \\
\hline $6-9$ & 55 & 30 & 85 \\
\hline $11-14$ & 75 & 71 & 146 \\
\hline $16-19$ & 70 & 75 & 145 \\
\hline $21-24$ & 80 & 60 & 140 \\
\hline $26-29$ & 47 & 37 & 84 \\
\hline $31-39$ & 41 & 40 & 87 \\
\hline $41-49$ & 42 & 45 & 81 \\
\hline $51-59$ & 56 & 30 & 86 \\
\hline 60 & 41 & 36 & 77 \\
\hline $\begin{array}{c}\text { Total } \\
\text { Population }\end{array}$ & $\mathbf{5 5 2}$ & $\mathbf{4 6 4}$ & $\mathbf{1 0 1 6}$ \\
\hline
\end{tabular}

Tabel 3 Educational Level

\begin{tabular}{|l|l|l|}
\hline No & \multicolumn{1}{|c|}{ Educational Level } & \multicolumn{1}{c|}{ Total } \\
\hline 1 & University & orang \\
\hline 2 & Senior High School & 51 orang \\
\hline 3 & Junior High School & 82 orang \\
\hline 4 & Elementary School & 211 orang \\
\hline 5 & Un-graduated from Elementary School & 152 orang \\
\hline 6 & No School & 35 orang \\
\hline & Total & $\mathbf{5 3 6}$ orang \\
\hline
\end{tabular}

Sources: Village Data 2018

\section{Research Result}

Based on the results of research conducted with informants consisting of 7 people 4 residents of Subdistrict of Tataaran 1 community and 3 grab drivers, the following results are obtained:

\section{What benefits do you get with an online taxi?}

The existence of an online taxi has a positive impact on the surrounding residents of Taataran 1 where residents feel the benefits of having opened an online taxi for the youth who used to spend time only in the aisles playing cards or drinks since they worked as an online taxi made them better no longer gather to drink and spend time with activities are not useful, by the online grab they move to gather around the shopping place like Alfa Mart, Indomart to wait for orders from consumers. This continues every day for grabs open up employment opportunities for them, but they're also other benefits are felt that grab makes it easy for people to find work in times of crisis due to those who don't know the address or the road to go to by grab / gojek they can be delivered safely due to they use this application and directly delivered to the home page according to the intended address. Safe facilities make these people more comfortable walking using grab online because of security and at the same time awake and avoid negative things, especially for female passengers. As well as other benefits for the community, namely when ordering food through an online application with the benefits of this taxi

What about the time spent when using a taxi online?

Online taxis are indeed a very popular vehicle at this time, using applications both for online vehicles wheeled 2 or 4 can all be accessed, both for vehicles used for traveling or ordering food. In all aspects, for example, time is very helpful, especially for students or employees of the local people who are dominating the area of Tataaran I where they are very helpful due to it does not slow down work, can send goods not late and arrive safely too. With the online grab application, they have no trouble finding a vehicle to do their activities. Online both grabcar and grab bike have good benefits.

\section{What about the cost when using an online taxi?}

Informant M.G "It's usually of expensive fees if we look like students and get bonuses due they keep using grab contents for free by ovo data when they go to campus it's a profitable" (Existing fees according to the route to be delivered, because I use Ovo application I often get a bonus to go to campus using only the bonus does not need to pay) For their citizens, there are those who think that the two means of transport are both earning a living so they don't have to depend on which transport they have to ride. Because as citizens they think they just got a vehicle during their activities, so that when there is a conflict between the micro driver and online taxi there are residents who have difficulty due to the absence of transportation to travel, a full week makes it difficult for residents to get a vehicle for it this is very unrest for citizens and also have an adverse impact both online taxi and micro drivers because of the strike action so that they automatically do not get the benefits. Cost is not a problem because the vehicle that is sought primarily for residents according to them is a sense of comfort itself and good service, the cost also depends on the distance but most importantly is the public likes to use online grab because of the bonus of the application as well so they are happier to use grab because the cost is cheap and can be found if there is already an urgent need

What do you think about the existence of online taxis in Tataaran? 
Regarding the existence of this online taxi, it was very well realized by the people in Tataaran 1 , even though the initial existence was about to become a conflict between the community members who worked as micro drivers and grab drivers. However, it was recognized this online taxi made it easy for residents who settled here. According to them with online taxi made daily activities easier if there are relatives who visit can be directly delivered to their home address. For online and micro taxis each has advantages and disadvantages, but for citizens of the two means of transportation are both helping the activities of existing residents.

\section{What is the best solution to avoid conflicts with a resident who rejects the existence of online taxis?}

By understanding each other both online taxi and micro driver then can minimize the conflict between the two camps as do the activities in each portion by not mutually anarchist and a dossier on the destruction of goods as conducted by the elements of the micro driver, they do not know if the vehicle is damaged may not belong to the online taxi but due to it has already been damaged all the losses should be experienced by the online taxi owner and also the strike as a form of protest conducted by the micro driver does not make the community experience difficulties especially students due to residents this has no effect or provide a deterrent, precisely those who feel they are being pushed down are themselves for not making a living.

\section{Discussion}

Public Perception of the existence of Online Taxi Grabs in Tataaran I, District of South Tondano.

Tataaran 1 community in Minahasa Regency experienced conflicts with online taxis entering the campus and even Tataaran / Tondano. This made public transportation or Micro drivers angry according to them, the existence of online taxis can hamper or even make them unable to find passengers for living. Structural functionalism is a theory whose understanding of society is based on organic systems models in biological sciences. That is, functionalism sees society as a system of several parts that are interconnected with one another. One part cannot be understood apart from the whole. Relationships occur when humans enter a pattern of relatively stable and continuous interaction and / or beneficial interdependence.

Then the pattern of social structure can be influenced by the number of different people, one's position and the role that individuals have in the social relations network [4]. What happens to the public is to ask for protest due to the entry of their online taxi is demanding if it impedes their relatives or family in finding income from the campus of Tondano. Social relations that occurred between members of the Tataaran community and micro drivers are because they live in addition to living in the same environment as kinship systems also affect the pattern of their interactions. in Sub-district of Tataaran 1, even though the initial existence was about to become a conflict between community members who worked as micro drivers and grab drivers. However, it was recognized this online taxi made it easy for the people who settled here according to them with the presence of online taxis doing daily activities becomes easier if there are relatives who visit can be directly delivered to their home address. For online and micro taxis each has advantages and disadvantages, but for the citizens of the two means of transportation are both helping the activities of existing residents.

The existence of an online taxi has a positive impact on the surrounding residents of Taataran 1 where residents feel the benefits of grab online taxis for young people who used to spend time in the aisles playing cards or drinking since they worked as an online taxi made them better no longer gather to drink and spend time with activities that are not useful, but with the online grab, they move to gather around the shopping place like Alfa Mart, Indomart to wait for orders from consumers. This continues every day for grabs open up employment opportunities for them, but there are also other benefits are felt, grab makes it easy for people to find work when the atmosphere is precarious due to those who do not know the address or the road to go to by using grab / gojek they can riding safely due to using this application and directly delivered to the home page according to the intended address.

Perception is a process involves the entry of messages or information into the human brain, through the perception of humans continuously making contact with their environment. The same thing with the people who are in Tataaran I is related to the entry of online taxis into their area with various conflicts that occur both citizens by taxi online or even a micro driver. Online taxis are indeed a very popular vehicle today, using applications for both wheeled and four-wheeled online vehicles, both of which are connected, to be used for traveling or ordering food.

However, being an online taxi driver does not have any constraints on the fact online taxis experience things that are detrimental to themselves and even lead to the blocking of their accounts for they can no longer make a living. The things that make them uncertain or reduced performance can be because of themselves, but here it is often said by online taxis they are the act of the passengers. By understanding each other, both online taxis and micro drivers, they can minimize conflicts between the two camps as they conduct activities in their respective portions without mutually anarchic and end up in the destruction of goods as done by individual micro drivers, they do not know if the vehicle is damaged may not belong to the online taxi but due to it has already been damaged all the losses should be experienced by the online taxi owner and also the strike as a form of protest by the micro driver does not make the community experience difficulties especially due to the students because this has no effect or provide a deterrent, precisely those who feel they are being pushed down are themselves for not making a living.

\section{CONCLUSION}

Based on the results of the research and discussion that has been conducted, the following conclusions are obtained: The public perception of Tataaran 1 regarding Grap online taxi activities can be seen from three important aspects namely the benefits of the time and cost of online taxis. In terms of benefits that using Grab makes it easier to do activities even more on pick up according to the point or (location) even though the house is far from the highway and delivered to the destination. In terms of time, using grab speeds up until the destination is different 
from public transportation is still spinning to take other passengers. In terms of cost, we are very happy because it can still be reached, especially also the availability of bonus offers, making it easier for users to get a bonus when ordering a grab.

For citizens who use online taxis to pay close attention on how to use online taxis and especially in assessing drivers. For local government, they should pay more attention to both online taxis and public transportation all work to earn a living and there is no justification for violence to damage vehicles that make residents feel uncomfortable.

\section{ACKNOWLEDGMENT}

The author would like to the Dean of Faculty of Social Science, Manado State University in supporting the publication of this article.

\section{REFERENCES}

[1] Sugiyono, Metode Penelitian Kuantitatif Kualitatif R\&D. Bandung: Alfabeta, 2011.

[2] Sugiyono, Metode Penelitian Kombinasi (Mixed Methods). Bandung: Alfabeta, 2016.

[3] M. B. Miles and M. A. Huberman, Analisis Data Kualitatif: Buku Sumber Tentang Metode-Metode Baru. 2012.

[4] S. Soekanto, Sosiologi suatu pengantar. Jakarta: Raja Grafindo Persada, 2012. 